\title{
Analisa Dampak Kualitas Produk Informasi terhadap Kepuasan Kerja Pengguna Sistem Informasi Manajemen pada Universitas Potensi Utama
}

\author{
Austin Alexander Parhusip \\ Universitas Potensi Utama \\ parhusip.austinalexander@gmail.com \\ Wisnu Rayhan Adhitya \\ Universitas Potensi Utama \\ wisnurayhanadhitya@gmail.com
}

\begin{abstract}
Abstrak Penelitian ini berjudul "Dampak Kualitas Produk Informasi Tehadap Kepuasan Kerja Pengguna Sistem Informasi Manajemen Pada Universitas Potensi Utama" yang bertujuan untuk menyelidiki pengaruh sistem-sistem informasi pada hasil-hasil terkait kerja. Penelitian ini fokus terhadap variabel kualitas produk informasi (Quality of Information Product), peran kedwiartian (Role Ambiguity), konflik peran (Role Conflict), kepuasan kerja (Job Satisfaction). Penelitian ini mengambil sampel para pegawai Universitas Potensi Utama. Sampel responden diambil dengan menggunakan teknik sampling aksidental sebanyak 120 responden. Hasil penelitian menunjukan terdapat pengaruh positif dari variabel kualitas produk informasi terhadap kepuasan kerjahal ini dapat dilihat dari nilai C.R $=2.555$, karena nilai C.R lebih besar dari 1,96 maka hipotesis 1 dterbukti. Hasil estimasi pengaruh peran konflik terhadap peran tingkat kepuasan kerja menunujkan tidak ada pengaruh dari variabel peran konflik terhadap kepuasan kerja, hal ini dapat dilihat dari nilai C.R $=-1,455$. Karena nilai C.R lebih kecil dari 1,96 maka dengan demikian hipotesis 2 tidak terbukti. Hasil estimasi pengaruh peran kedwiartian terhadap peran konflik diperoleh koefisien path $=0,326$ (positif) dan nilai C.R $=1,662$. Karena nilai C.R lebih kecil dari 1,96 menunjukan tidak ada pengaruh, dengan demikian hipotesis 3 tidak terbukti. Pada hasil estimasi pengaruh peran kedwiartian terhadap pencarian media nilai C.R $=2.013$. Karena nilai C.R lebih besar dari 1,96, berarti ada pengaruh yang positif dan signifikan dari kualitas produk informasi terhadap peran kedwiartian. dengan demikian hipotesis 4 terbukti. Sedangkan pada estimasi pengaruh peran konflik terhadap pencarian media diperoleh nilai C.R $=-1.160$. Karena nilai C.R lebih kecil dari 1,96 maka berarti tidak ada pengaruh kualitas produk informasi terhadap peran konflik, dengan demikian hipotesis 5 tidak terbukti.
\end{abstract}

Kata Kunci Kualitas produk informasi, Peran kedwiartian, Peran konflik, Kepuasan kerja 


\section{PENDAHULUAN}

Dunia kerja sekarang sedang mengalami sebuah badai perubahan, baik itu didalam organisasi bisnis, institusi pendidikan, maupun institusi pemerintahan. Perubahan itu sangat berkaitan dengan adanya teknologi informasi yang saat ini sudah sangat berkembang dan pentingnya kualitas produk informasi yang dihasilkan teknologi informasi menurut Haag dan Keen (1996) bahwa teknologi informasi adalah seperangkat alat yang membantu anda bekerja dengan informasi dan melakukan tugas-tugas yang berhubungan dengan pemrosesan informasi. Implementasi Teknologi Informasi (TI) untuk mendukung kegiatan operasional suatu organisasi baik dalam skala kecil maupun besar, berkembang menjadi kebutuhan mendasar dalam menghadapi era industri 4.0 dan good governance. Sistem informasi yang didukung TI dapat memberikan nilai tambah bagi organisasi jika didesain menjadi sistem informasi yang efektif, sistem informasi yang menandakan bahwa system tersebut sukses.

Delone and Mclean (1992) mengajukan suatu model kesuksesan sistem informasi yang terdiri dari 6 kategori yaitu : Kualitas sistem, kualitas Informasi, kegunaan, kepuasan pemakai, pengaruh pribadi, dan pengaruh organisasi. Dalam penelitian ini akan memakai hubungan antara kualitas informasi yang dihasilkan dengan kepuasan penggunanya. Kualitas informasi tersebut berkaitan dengan karakteristik informasi sedemikian rupa sehingga output yang dihasilkan oleh sistem informasi tersebut dapat bermanfaat bagi penggunanya. Hal tersebut mengakibatkan kualitas produk informasi tersebut mempunyai dampak langsung terhadap job satisfaction, adapun pengaruh yang tidak langsung yang diakibatkan oleh kualitas produk informasi terhadap job satisfaction yaitu Role Ambiguity (RA) dan Role Conflict (RC). RA dan RC ini sebagai mediator antara pengaruh tersebut dimana mereka adalah salah satu unsur stressor yang paling dominan didalam lingkungan kerja.

Untuk itu diharapkan dengan adanya pengukuran keefektifan sistem informasi ini dapat menjadi bahan pertimbangan bagi para desainer SI untuk mendesain sistem informasi bagi perusahaannya dan dapat menganalisis seberapa jauh peranan SI ini untuk membantu mencapai tujuan perusahaan. Kita tidak ingin implementasi SI yang membutuhkan biaya yang sangat mahal ini tidak memberikan dampak yang positif terhadap perusahaan ataupun pemanfaatannya tidak dilakukan secara maksimal.

\section{LANDASAN TEORI}

\section{Sistem Informasi}

Sistem informasi merupakan seperangkat komponen yang saling berhubungan yang berfungsi mengumpulkan, memproses, menyimpan dan mendistribusikan informasi untuk mendukung pembuatan keputusan dan pengawasan dalam organisasi (Laudon dan laudon,2000). Perkembangan teknologi komputer atau website. Bodnar dan Hopwood (2000) menjelaskan bahwa sistem informasi berbasis teknologi komputer adalah satu pengabungan perangkat keras dan perangkat lunak yang dirancang untuk mengubah data menjadi informasi yang bermanfaat. penggunaan perangkat keras dan perangkat lunak tersebut dimaksudkan untuk menghasilkan

Sistem informasi menajemen dibeberapa perusahaan besar setidak-tidaknya memiliki 5 komponen, yaitu :

1. Sistem Pemprosesan Data (Data Proscesing System)

2. Sistem Pelaporan Manajemen (Management Reporting System) 
3. Sistem Pendukung Dalam Pengambilan Keputusan (Decision Support System)

4. Sistem Otomasi Kantor (Office Automatic System)

5. Sistem Pintar (Expert System)

Setiap desainer sistem informasi harus membuat konsep bagaimana sistem informasi tersebut dapat diterapkan ke dalam organisasi yang bersangkutan. Hal tersebut harus diperhitungkan matang oleh desainer, dengan tujuan sistem informasi dapat diterapkan secara efektif. Menurut Leavitt ada elemen lain seperti organization structure, business processes, people yang dapat mempengaruhi proses mendesain SI tersebut.

\section{Gambar 2.1}

\section{Fundamental components of an organization}

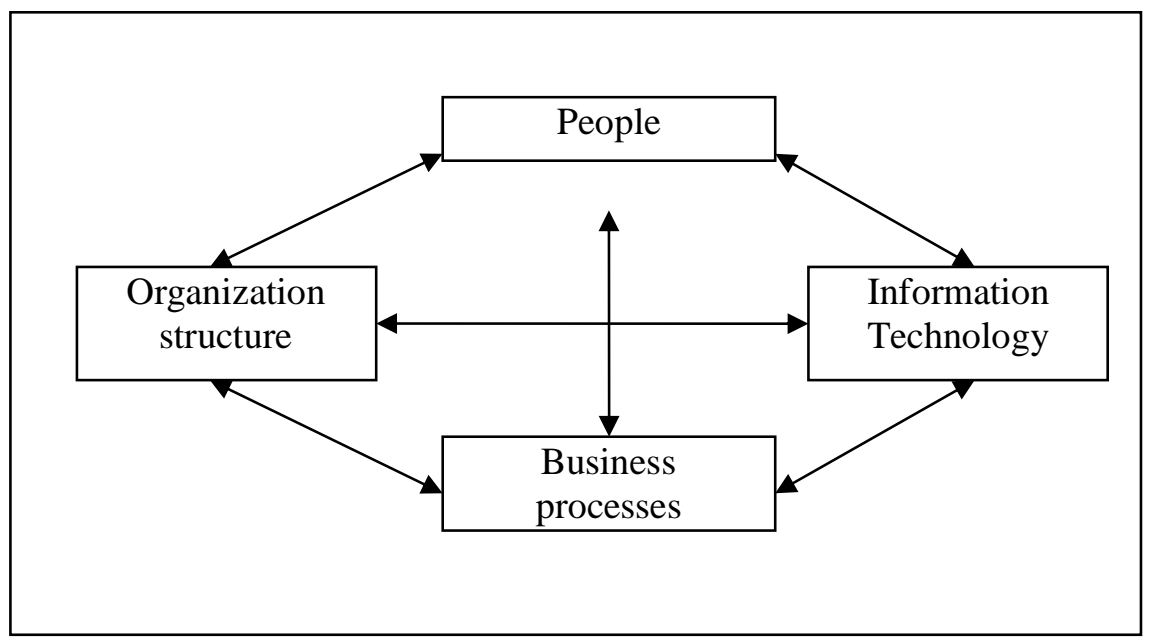

Sumber : Carol V, managing information technology, 2006, fifth edition

Dari gambar 2.1. di atas menjelaskan bahwa apabila terjadi perubahan teknologi di dalam perusahaan akan memberikan dampak juga terhadap ketiga unsur lainnya. Setelah melihat perubahan yang begitu kompleks di dalam satu perubahan yang lainnya, Daniel W. Dehayes (2006) memberikan prinsip seperti: "Each time we change characteristics of one or more of these four components we must consider compensating changes in the others".

Hal ini menimbulkan masalah, seperti komponen mana yang harus didahulukan. Hal ini sulit untuk diprediksi, sehingga menimbulkan dilema bagi setiap perubahan. Namun hal tersebut tergantung pada purpose, process dan Organizational settings (Markus and Robey, 1998), sehingga perubahan ini dapat diprediksi terlebih dahulu mana komponen lain yang diprioritaskan.

\section{Kepuasan Kerja}

Salah satu cara pengukuran kinerja dalam pengimplementasian SI adalah dengan menggunakan User satisfaction, ini merupakan cara terbaik untuk mengkomunikasikan penilaian manajer tentang implementasi system informasi terhadap informasinya.Berikut adalah kriteria penilaian mengenai user satisfaction yang dapat digunakan untuk survey mengenai pengukuran kinerja terhadap implementasi SI : 
Tabel 2.1

\section{Criteria for user satisfaction surveys}

\begin{tabular}{|c|}
\hline \multirow{2}{*}{$\begin{array}{l}\text { Criteria for user satisfaction surveys } \\
\text { User satisfaction criteria for invidual systems }\end{array}$} \\
\hline \\
\hline - $\quad$ Accuracy of output \\
\hline Quality / reability of output \\
\hline Completeness of output \\
\hline Relevance of output \\
\hline Completeness of accesability of database \\
\hline Currency of database \\
\hline Response time \\
\hline Availability \\
\hline Mean time between failures \\
\hline Downtime or malfunction recovery time \\
\hline Charges / costs \\
\hline Quality of system documentationA \\
\hline Number and severity of security breaches \\
\hline Ease of operation \\
\hline Ease of making changes \\
\hline Increased confidence in decisions and actions based on systems output \\
\hline - $\quad$ Extent if achieviagexpexted benefit \\
\hline User satisfaction criteria for IS units \\
\hline - $\quad$ Quality of system specification document \\
\hline Size of request backlog or worldoad \\
\hline Project complete on time and within budget \\
\hline Speed and witch request system cnanges are made \\
\hline Professionalism of IS staff \\
\hline Nature of relationship with IS staff \\
\hline Business knowledge os IS staff \\
\hline Quality of user training \\
\hline User fee ling of involvement in system management \\
\hline
\end{tabular}

Sumber : Daniel W. Dehayes, managing information technology, fifth edition

\section{Peran Konflik}

Peran konflik ini timbul karena adanya perbedaan persepsi atau harapan dari orang lain terhadap suatu individu, karena hal ini menimbulkan kesulitan apabila seseorang menerima berbagai macam harapan tanpa adanya penolakan terhadap harapan yang lainnya. Di dalam dunia kerja peran konflik ini sudah menjadi hal yang umum, terutama bagi karyawan yang memiliki pekerjaan lain diluar organisasi tersebut. Menurut Marretih (2013), faktor-faktor yang mempengaruhi konflik peran adalah sebagai berikut:

a. Tekanan waktu, semakin banyak jam kerja, semakin sedikit waktu yang dihabiskan bersama keluarga.

b. Ukuran dan dukungan keluarga, semakin banyak anggota keluarga, semakin banyak konflik, semakin banyak dukungan keluarga, semakin sedikit konflik.

c. Kepuasan kerja, semakin tinggi kepuasan kerja, semakin sedikit konflik.

d. Pernikahan dan kepuasan hidup, ada anggapan bahwa wanita profesional berdampak negatif pada pernikahannya.

e. Ukuran perusahaan, yaitu banyaknya karyawan perusahaan yang dapat mempengaruhi konflik peran ganda seseorang. 


\section{Peran Kedwiartian}

Peran kedwiartian ini timbul akibat dari adanya ketidakjelasan dan ketidaktahuan peran individu tersebut. Mereka tidak tahu apa yang harus dilakukan dalam situasi tertentu. Robbins (2003) menunjukkan bahwa ambiguitas peran muncul ketika pemahaman tentang ekspektasi peran (role expectation) tidak jelas, dan seseorang tidak yakin dengan apa yang dilakukannya.Menurut Kreitner (2004), "Role ambiguity is others' expectations are unknown". Perubahan didalam organisasi memerlukan sebuah training ataupun pemberian penjelasan lebih terhadap karyawannya. Proses adaptasi berperan penting dalam perubahan ini. Faktor skill menentukan waktu adaptasi, sehingga setiap individu memiliki waktu yang bervariasi terhadap penerimaan dalam perubahan yang terjadi di perusahaan.

Berikut merupakan model perjuangan yang akan dilakukan berdasarkan hipotesis yang telah dianalisis :

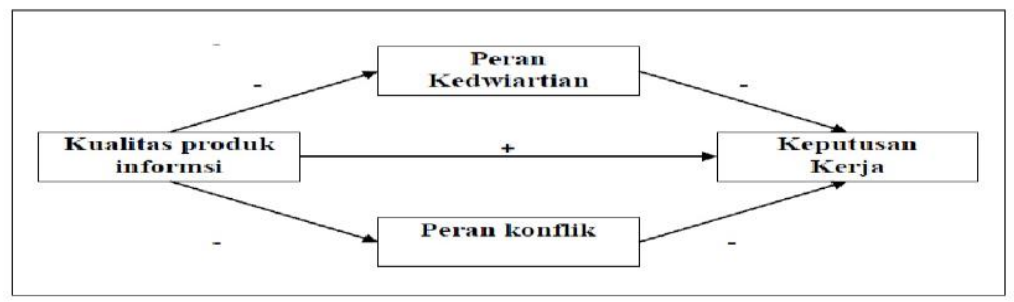

Gambar 2.2 Model Penelitian

Setelah melakukan hipotesa sebelumnya terhadap empat variable di atas sehingga dapat dibentuk suatu model. Model tersebut menunjukkan hubungan antara kualitas produk informasi dan kepuasan kerja. Terdapat satu efek langsung dan 2 efek tidak langsung. Dalam waktu yang sama meningkatnya kualitas produk informasi dapat menyebabkan penurunan tingkat peran kedwiartian dan konflik. Dan sebaliknya penurunan peran konflik dan kedwiartian dapat menyebabkan kenaikan tingkat kepuasan kerja. Oleh sebab itu kualitas produk informasi mempunyai pengaruh kerja. Kualitas produk informasi mempunyai pengaruh tidak langsung terhadap kepuasan kerja dan memberikan efek langsung terhadap peran konflik dan kedwiartian.

\section{METODOLOGI PENELITIAN}

Dalam penelitian ini dilakukan dalam bentuk deskriptif Research dan Eksplanasi.yang bertujuan untuk menganalisis mengenai hubungan antara Peran kedwiartian, peran konflik, kepuasan kerja dan kualitas produk informasi.Target populasi dalam penelitian ini adalah semua individu yang menerima dan menggunakan informasi yang disediakan oleh sistem informasi di tempat kerjanya. Dan sample dalam penelitian ini adalah pegawai Universitas Potensi Utama, dengan berbagai jabatan yang menggunakan dan menerima informasi yang disediakan sistem informasi untuk mendukung kegiatan operasional akademik sehari - hari.

Data yang digunakan adalah data primer yaitu data langsung yang langsung diperoleh dari sumber data pertama dilokasi penelitian atau objek penelitian. Teknik penarikan sample pada penelitian kali ini adalah dengan menggunakan teknik aksidental didasarkan pada kemudahan (convenience) dimana sample dapat terpilih karena berada pada waktu, situasi dan tempat yang tepat (Prasetyo \& Lina, 2005). Data diambil dengan menyebarkan kuesioner atau angket kepada semua pegawai Universitas Potensi Utama. 
Karena pengujian hipotesa menggunakan Simultaneous Equation Model (SEM), jumlah kuesioner yang bisa diproses paling tidak sebanyak 120 responden (Hair et al, 2006). Variable yang diteliti terdiri dari empat variable yang diklasifikasikan sebagai berikut:

1. Variabel dependen yang terdiri dari: Peran kedwiartian, peran konflik, kepuasan kerja.

2. Variabel independen yang terdiri dari : kualitas produk informasi.

Defenisi operasional keempat tersebut adalah sebagai berikut :

1. Kualitas produk informasi didefenisikan sebagai suatu tingkatan dimana informasi yang dihasilkan oleh system informasi tersebut telah sesuai dengan kriteria yang telah ditetapkan seperti relevan, tepat waktu dan lain - lain. Untuk mengetahui tingkat kualitas produk informasi, responden diminta untuk menjawab 9 (sembilan) pertanyaan yang diadopsi dari kuesioner Bailey dan perason (1983) dan Ives et al. (1983). Pengukuran variable menggunakan skala interval dari skor / skala 1 yang menunjukkan tingkat kualitas produk informasi rendah sampai dengan skor / skala 6 yang menunjukkan tingkat kualitas produk informasi tinggi.

2. Kepuasan kerja didefenisikan sebagai suatu tingkatan dimana seseorang telah merasakan nyaman, puas dan cocok dengan pekerjaan yang dilakukan. Untuk mengetahui tingkat kepuasan kerja, responden diminta untuk menjawab 5 (lima) pertanyaan yang diadopsi dari kuesioner Hackman dan oldham (1975). Pengukuran variable menggunakan skala interval dari skor / skala 1 yang menunjukkan tingkat kepuasan kerja rendah sampai dengan skor / skala 6 yang menunjukkan tingkat kepuasan kerja tinggi.

3. Peran kedwiartian didefenisikan sebagai suatu tingkatan dimana seseorang dipengaruhi oleh kualitas informasi yang dihasilkan sistem informasi untuk dapat mendukung proses kerjanya. Untuk mengetahui tingkat peran kedwiartian ini, responden diminta untuk menjawab 6 (enam) pertanyaan yang diadopsi dari kuesioner Rizzo et al (1975). Pengukuran variabel menggunakan skala interval dari skor/skala 1 yang menunjukkan tingkat peran kedwiartian rendah sampai dengan skor / skala 6 yang menunjukkan tingkat kedwiartian tinggi.

4. Peran konflik didefenisikan sebagai suatu tingkatan dimana seseorang dipengaruhi oleh ketidakcocokan seseorang didalam pekerjaan maupun lingkugan kerjanya atau adanya benturan nilai - nilai atau kepentingan dengan individu lainnya. Untuk mengetahui tingkat peran konflik ini, responden diminta untuk menjawab 8 (delapan) pertanyaan yang diadopsi dari kuesioner Rizzo et al (1975). Pengukuran variable menggunakan skala interval dari skor / skala 1 yang menunjukkan tingkat peran konflik rendah sampai dengan skor / skala 6 yang menunjukkan tingkat konflik tinggi.

\section{HASIL PENELITIAN}

Penelitian ini menggunakan model analisis structural equation model (SEM) yang dibantu dengan program aplikasi AMOS. Model persamaan structural (Structural Equation Modeling, SEM) merupakan teknik analisis multivariat yang memungkinkan peneliti untuk menguji hubungan antar variabel yang kompleks baik secara recursive (hubungan timbal balik) maupun non-recursive untuk memperoleh gambaran menyeluruh mengenai keseluruhan model. SEM berlandaskan pada pengujian teori, sehingga dibutuhkan landasan teori yang kuat. Variabel laten di dalam SEM dibentuk dari indikator berdasarkan model refleksif, yakni variabel laten merupakan pencerminan dari indikator - indikatornya. Hair et al (1998) dalam Ghozali (2004) menjelaskan bahwa model 
persamaan structural didasarkan pada hubungan kausalitas, dimana perubahan satu variabel diasumsikan akan berakibat pada perubahan variabel lainnya. Kuatnya hubungan kausalitas antara dua variabel yang diasumsikan oleh peneliti bukan terletak pada metode analisis yang dipilih, tetapi terletak pada justifikasi (pembenaran) secara teoritis untuk mendukung analisis. Jadi jelas bahwa hubungan antar variabel dalam model merupakan deduksi dan teori.

persamaan regresi berganda disusun sebagai berikut:

$$
\begin{aligned}
& J S=\alpha_{1}+\beta_{1} R A+\beta_{2} R C+\beta_{3} Q I P+\varepsilon_{1} \\
& A=\alpha_{2}+\beta_{2} Q I P+\varepsilon_{2} \\
& R C=\alpha_{3}+\beta_{3} Q I P+\varepsilon_{3}
\end{aligned}
$$

Dimana :

JS : Kepuasan kerja

RA : Peran Kedwiartian

RC : Peran konflik

QIP: Kualitas Produk Informasi

Tujuan riset ini untuk mengetahui pengaruh kualitas informasi terhadap kepuasan kerja pengguna sistem informasi Universitas Potensi Utama. Dalam penelitian ini, data diperoleh melalui penyebaran penilaian atas dampak penggunaan sistem informasi manajemen tersebut. Metode analisis data yang digunakan dalam penelitian ini adalah analisis deskriptif yang meliputi penggambaran karakteristik responden yang menjadi sampel penelitian dan analisis kuantitatif dengan analisi SEM dengan program AMOS.

Hasil pengujian yang telah dilakukan dengan software SPSS, maka diperoleh hasil pengujian sebagai berikut :

Tabel 4.1

Uji Reliabilitas

\begin{tabular}{|l|r|r|r|r|}
\hline & $\begin{array}{r}\text { Scale Mean if } \\
\text { Item Deleted }\end{array}$ & $\begin{array}{c}\text { Scale } \\
\text { Variance if } \\
\text { Item Deleted }\end{array}$ & $\begin{array}{c}\text { Corrected } \\
\text { Item-Total } \\
\text { Correlation }\end{array}$ & $\begin{array}{c}\text { Cronbach's } \\
\text { Alpha if Item } \\
\text { Deleted }\end{array}$ \\
\hline Kualitas Produk & 13.5557 & 2.088 & 0.596 & 0.642 \\
Informasi & 13.421 & 2.193 & 0.581 & 0.658 \\
Peran Kedwiartian & 14.5653 & 2.212 & 0.382 & 0.746 \\
Peran Konflik & 14.171 & 1.328 & 0.646 & 0.614 \\
Kepuasan Kerja & & & \\
\hline
\end{tabular}

Sumber : Data diolah

Berdasarkan pada tabel 4.1 dapat disimpulkan bahwa semua pertanyaan yang digunakan untuk mengukur masing - masing variabel penelitian dapat diandalkan atau reliable, karena memiliki nilai Cronbach's Alpha yang disyaratkan yaitu di atas nilai kritis $(>0.60)$. Pengujian model yang diusulkan dalam penelitian ini dilakukan dengan menggunakan metode statistik multivariate Structural Equation Modeling (SEM) dengan menggunakan AMOS dengan cara mengestimasi model dari data yang ada. 
Penggambaran diagram jalur dan besarnya koefisien path, dapat ditunjukkan dalam gambar berikut :

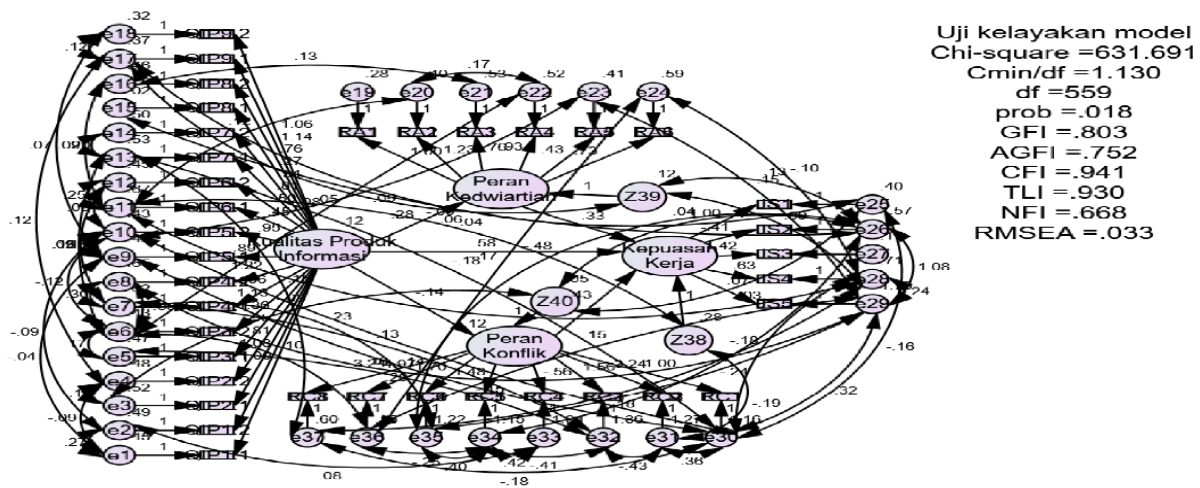

Gambar 4.1. Hasil Diagram Jalur

Evaluasi terhadap model multifactor dari pengukuran di atas menghasilkan indeks-indeks goodness of fit sebagaimana disajikan pada tabel berikut :

Tabel 4.2. Hasil Goodness of Fit Model Pengukuran

\begin{tabular}{|l|l|l|l|}
\hline Index & Cut Off Value & Hasil & Evaluasi Model \\
\hline Chi-square & & 631,691 & Good \\
\hline Cmin/df & $\leq 2,00$ & 1,130 & Fit \\
\hline Probabilitas & $\geq 0,05$ & 0,018 & Adequate Fit \\
\hline GFI & $\geq 0,90$ & 0,803 & Adequate Fit \\
\hline AGFI & $\geq 0,90$ & 0,752 & Adequate Fit \\
\hline CFI & $\geq 0,90$ & 0,941 & Fit \\
\hline TLI & $\geq 0,95$ & 0,930 & Adequate Fit \\
RMSEA & $\leq 0,08$ & 0.033 & Fit \\
\hline
\end{tabular}

Indeks - indeks goodness of fit model pengukuran (measurement model) pada tabel 4.2 di atas menunjukkan hasil yang baik, sehingga model yang ada telah memberikan estimasi model yang fit dan dapat menjadi model structural penuh pada model awal tersebut.

Hipotesis yang mempresentasikan pengaruh suatu konstruk terhadap konstruk lain diuji dengan memeriksa apakah koefisien path (standardized estimate) yang menghubungkan kedua konstruk tersebut signifikan pada taraf signifikansi $=0.05$ (one - tailed). Hasil estimasi koefisien path terhadap model yang diajukan dengan program AMOS, dapat dilihat pada tabel berikut ini :

Tabel 4.3 Hasil Goodness of Fit Model Pengukuran

\begin{tabular}{|c|c|c|c|c|}
\hline Hipotesis & $\begin{array}{c}\text { Path } \\
\text { Hubungan }\end{array}$ & $\begin{array}{l}\text { Standardizaed } \\
\text { Estimated }\end{array}$ & C.R & Keterangan \\
\hline H 1 & $\begin{array}{l}\text { Kualitas Produk } \\
\text { Informasi } \rightarrow \\
\text { Kepuasan Kerja }\end{array}$ & 0.577 & 2.555 & Terbukti \\
\hline $\mathrm{H} 2$ & $\begin{array}{l}\text { Peran Konflik } \\
\rightarrow \text { Kepuasan } \\
\text { Kerja }\end{array}$ & -0.430 & -1.455 & $\begin{array}{c}\text { Tidak } \\
\text { Terbukti }\end{array}$ \\
\hline H3 & $\begin{array}{l}\text { Peran } \\
\text { Kedwiartian } \rightarrow \\
\text { Kepuasan Kerja }\end{array}$ & 0.326 & 1.662 & $\begin{array}{l}\text { Tidak } \\
\text { Terbukti }\end{array}$ \\
\hline H4 & $\begin{array}{l}\text { Kualitas Produk } \\
\text { Informasi } \rightarrow \\
\text { Peran } \\
\text { Kedwiartian }\end{array}$ & 0.281 & 2.013 & Terbukti \\
\hline H5 & $\begin{array}{l}\text { Kualitas Produk } \\
\text { Informasi } \rightarrow \\
\text { Peran Konflik }\end{array}$ & -0.138 & -1.610 & $\begin{array}{l}\text { Tidak } \\
\text { Terbukti }\end{array}$ \\
\hline
\end{tabular}

Sumber : Data diolah 
Berdasarkan hasil estimasi model pada Tabel 4.3, interpretasi masing-masing pengujian hipotesis di atas dapat diuraikan sebagai berikut:

Pernyataan hipotesis awal dari hipotesis 1 adalah sebagai berikut: H1: Kualitas produk informasi mempunyai pengaruh positif terhadap tingkat kepuasan kerja.

Hasil estimasi pengaruh kualitas produk informasi terhadap peran kedwiartian diperoleh koefisien path (standardized estimate) $=0.577$ (positif). Uji signifikansi koefisien ini diperoleh nilai C.R $=2.555$. Karena nilai C.R lebih besar dari 1,96 maka tolak Ho pada taraf signifikan $5 \%$, yang berarti ada pengaruh positif dari variabel kualitas produk informasi terhadap kepuasan kerja. Dengan demikian hipotesis 1 terbukti.

Pernyataan hipotesis awal dari hipotesis 2 adalah sebagai berikut: H2: Peran konflik mempunyai pengaruh negatif terhadap tingkat kepuasan kerja.

Hasil estimasi pengaruh peran konflik terhadap peran tingkat kepuasan kerja diperoleh koefisien path $=-.0,430$ (negatif) dan nilai $C . R=1,455$. Karena nilai C.R lebih kecil dari 1,96 maka terima Ho pada taraf signifikan 5\%, yang berarti tidak ada pengaruh dari variabel peran konflik terhadap kepuasan kerja. Dengan demikian hipotesis 2 tidak terbukti.

Pernyataan hipotesis awal dari hipotesis 3 adalah sebagai berikut: H3: Peran kedwiartian mempunyai pengaruh negatif terhadap tingkat kepuasan kerja.

Hasil estimasi pengaruh peran kedwiartian terhadap peran konflik diperoleh koefisien path $=0,326$ (positif) dan nilai C.R $=1,662$. Karena nilai C.R lebih kecil dari 1,96 maka tolak Ho pada taraf signifikan 5\%, yang berarti tidak ada pengaruh dari variabel peran kedwiartian terhadap kepuasan kerja. Dengan demikian hipotesis 3 tidak terbukti.

Pernyataan hipotesis awal dari hipotesis 4 adalah sebagai berikut: $\mathrm{H} 4$ : Kualitas produk informasi mempunyai pengaruh negatif terhadap peran kedwiartian.

Hasil estimasi pengaruh peran kedwiartian terhadap pencarian media diperoleh koefisien path $=0.281$ (positif) dan nilai C.R $=2.013$. Karena nilai C.R lebih besar dari 1,96, maka tolak Ho pada taraf signifikan $5 \%$, yang berarti ada pengaruh yang positif dan signifikan dari kualitas produk informasi terhadap peran kedwiartian. Dengan demikian hipotesis 4 terbukti.

Pernyataan hipotesis awal dari hipotesis 5 adalah sebagai berikut: H5 : Kualitas produk informasi mempunyai pengaruh negatif terhadap peran konflik.

Hasil estimasi pengaruh peran konflik terhadap pencarian media diperoleh koefisien path $=-0.38$ (negatif) dan nilai C.R $=-1.160$. Karena nilai C.R lebih kecil dari 1,96 maka terima Ho pada taraf signifikan 5\%, yang berarti tidak ada pengaruh kualitas produk informasi terhadap peran konflik. Dengan demikian hipotesis 5 tidak terbukti.

\section{PEMBAHASAN}

berikut :

Berdasarkan hasil penelitian diatas, maka dapat di interpretasikan sebagai

1. Hasil analisis untuk variabel kualitas produk informasi mempunyai pengaruh yang positif dan signifikan terhadap kepuasan kerja. Adanya pengaruh ini berarti apabila semakin baik penerapan teknologi informasi, maka hal ini akan menyebabkan kepuasan kerja dari pegawai juga meningkat. Dengan demikian, 
kualitas produk informasi sebagai kualitas informasi yang dihasilkan akan meningkatkan kepuasannya dalam pekerjaaan. Untuk itu kepuasan kerja menjadi sangat penting dalam lingkungan organisasi, karena angkatan kerja yang puas akan memberikan produktivitas yang lebih tinggi dikarenakan sedikitnya gangguan dalam pekerjaannya.

2. Peran konflik tidak berpengaruh kepada kepuasan kerja. Dengan demikian dapat dijelaskan bahwa adanya perbedaan kepentingan, harapan dan persepsi dalam penerapan teknologi informasi tidak menjadikan kepuasan kerja karyawan menurun. Dengan demikian, karyawan dapat menyesuaikan diri dengan beberapa kepentingan yang mereka miliki dalam pekerjaan baik kepentingan dalam tempar kerja maupun kepentingan diluar tempat kerja.

3. Hasil analisis untuk variabel peran kedwiartian mempunyai pengaruh yang signifikan terhadap kepuasan kerja. Hal ini menjelaskan bahwa adanya ketidakjelasan tugas atau pekerjaan bagi setiap individu, akibat ketidakjelasan kerja tersebut yang menyebabkan pegawai melakukan pekerjaanya sesuai yang mereka pahami walaupun belum tentu sesuai dengan peraturan di organisasi sehingga meningkatkan kepuasan kerja. Tentunya hal tersebut akan berdampak kurang baik bagi kondisi lingkungan kerja.

4. Kualitas produk informasi berpengaruh signifikan terhadap peran kedwiartian dengan pengaruh yang positif. Dengan demikian, kualitas produk informasi yang makin baik akan akan menyebabkan meningkatnya ketidakjelasan individu dalam penggunaan teknologi informasi tersebut, hal ini akan berdampak pada ketidakkepuasan kerja pegawai yang makin tinggi dan memburuknya kinerja dalam organisasi.

5. Kualitas produk informasi tidak berpengaruh terhadap peran konflik. Dengan demikian, kualitas produk informasi yang ada pada saat ini kurang memberikan kontribusi yang signifikan dalam mengurangi konflik-konflik yang ada pada karyawan. Sehingga hal ini harus menjadikan perhatian tersendiri bagi organisasi untuk mengurangi atau mencegah terjadinya konflik agar kepuasan kerja karyawan tidak menurun dengan adanya penerapan teknologi informasi.

6. Dengan demikian, dari hasil penelitian ini tidak sepenuhnya mendukung hipotesis yang diajukan dalam penelitian ini, yang mana sebagian berpengaruh dan sebagian lagi tidak berpengaruh. Namun pada dasarnya, hasil penelitian ini sejalan dengan penelitian terdahulu yang dilakukan oleh Kailash Joshi dan Arun Rai, Hasil penelitian terdahulu membuktikan bahwa variabel seperti kualitas produk informasi, peran kedwiartian,dan peran konflik berperan di dalam mempengaruhi kepuasan kerja.

\section{KESIMPULAN}

Penelitian ini dilakukan terhadap 120 responden yang merupakan pegawai Universitas Potensi Utama. Dalam penelitian ini terdapat 5 (lima) hipotesis yang diujikan menggunakan AMOS versi 22 dan SPSS versi 22.0. Dari ke 5 (lima) hipotesis tersebut terdapat 3 (tiga) hipotesis yang tidak terbukti yaitu hipotesa 2 (dua), hipotesa 3 (tiga) dan hipotesa 5 (lima), sedangkan 2 (dua) hipotesis lainnya yaitu hipotesa 1 (satu), dan hipotesa 4 (empat) terbukti dan terdukung oleh data.

Penelitian ini bertujuan untuk menguji dampak dari kualitas produk informasi terhadap kepuasan kerja para pengguna sistem informasi manajemen pada Universitas Potensi Utama. Penelitian ini dianalisa dengan Structural Equation Model (SEM). Dari hasil analisis yang telah dilakukan atas dasar hasil pengolahan data penelitian, dapat 
ditarik kesimpulan sebagai berikut:

1. Kualitas produk informasi berpengaruh positif terhadap tingkat kepuasan kerja seseorang dalam menjalankan pekerjaannya didalam suatu organisasi dengan nilai estimasi sebesar 0,577 (positif) dan nilai CR sebesar 2,555.

2. Peran konflik tidak mempunyai pengaruh terhadap kepuasan kerja seseorang dalam menjalankan pekerjaannya didalam organisasi tersebut. dengan nilai estimasi sebesar 0,430 (negatif) dan nilai CR sebesar -1,455.

3. Peran kedwiartian tidak mempunyai pengaruh terhadap tingkat kepuasan kerja seseorang dalam menjalankan pekerjaannya. dengan nilai estimasi sebesar 0,326 (positif) dan nilai CR sebesar 1,662.

4. Kualitas produk informasi mempunyai pengaruh positif terhadap peran kedwiartian pada organisasi tersebut. dengan nilai estimasi sebesar 0,281 (positif) dan nilai CR sebesar 2,013.

5. Kualitas produksi informasi tidak berpengaruh terhadap peran konflik pada organisasi tersebut. dengan nilai estimasi sebesar 0,138 (negatif) dan nilai CR sebesar -1,610.

\section{UCAPAN TERIMA KASIH}

Puji dan syukur kami panjatkan kehadirat Tuhan Yang Maha Esa , atas rahmat, dan karunia-Nya sehingga penulis dapat menyelesaikan laporan akhir penelitian ini dengan judul "Analisa Dampak Kualitas Produk Informasi Terhadap Kepuasan Kerja Pengguna Sistem Informasi Manajemen Pada Universitas Potensi Utama”.

Penulis juga ingin mengucapkan terima kasih yang sebesar-besarnya kepada semua pihak yang telah membantu kelancaran penelitian ini, yaitu antara lain;

1. Bapak Bob Subhan Riza, ST, M.Kom selaku Ketua Yayasan Potensi Utama, yang telah memberikan kesempatan dan dukungan sehingga pengembangan ilmu di Universitas Potensi Utama Medan dapat terus berkembang.

2. Kepada Kementerian Riset Teknologi Dan Pendidikan Tinggi Republik Indonesia (RISTEK-DIKTI) yang telah memberi dukungan financial terhadap penelitian ini.

3. Serta rekan-rekan di Universitas Potensi Utama Medan, dan semua pihak yang tidak bisa disebutkan satu persatu, yang telah memberikan saran, kritik, dan doanya juga.

Tentu saja penelitian ini memiliki banyak kelemahan yang perlu disempurnakan untuk masa yang akan datang. Saran dan kritik bagi penulis akan sangat diperlukan dalam proses penyempurnaan maupun pengembangan bidang keilmuan ini

\section{DAFTAR PUSTAKA}

Bambang Prasetyo, Lina Miftahul Jannah. 2005. Metode Penelitian Kuantitatif:Teori dan Aplikasi. Jakarta: Penerbit PT.Raja Grafindo Persada.

Bailey, J.E. and S.W Pearson.1983, Development of a Tool for Measuring and Analysing Computer Satisfaction, Management Science 29 May.

Bodnar, George, William, Hopwood, 2000, Sistem Informasi Akuntansi, Edisi pertama, penerjemah, Amir Abadi Jusup dan Rudi M. Tambunan, penerbit salemba empat, Jakarta. 
Brown, Carol V., DeHayes, Daniel W., Hoffer, Jefferey A., Wainright Martin, E., Perkins, William C. (2009). Managing Information Technology. (6th edition). New Jersey: Pearson Prentice Hall.

Delone, W. H., \& Mclean , E. R. (1992). Information System Success: The Quest For Dependent Variable. Information Systems Research, 3(1), 60-95.

Fornell, C. G., \& Larcker, D. F. (1981). Evaluating Structural Equation Models with Unobservable Variables and Measurement Error. Journal of Marketing Research 18(1), pp.39-50.

Gupta, N. \& Beehr, T.A. (1979) Job Stress And Employee Behavior. Organizational Behavior And Human Performance, 23, 373-387.

Hackman, J.R. \& Oldham, G.R. (1975) Development Of The Job Diagnostic Survey. Journal Of Applied Psychology, 60, 159-170.

Hair, J.F, R.E.Anderson, R.L. Tatham, W.C. Black, Multivariate Data Analysis With Readings. Prentice Hall, Upper Saddle River. Nj. 2006.

Houe, R. J. \& Rizzo, J. R. (1972) Role Conflict And Role Ambiguity As Critical Variables In A Model Of Organizational Behavior. Organization Behavior And Human Performance, 7, 467-505.

Ives, et al., "The measurement of user information satisfaction," Communications of the ACM, vol. 26, no. 10, pp. 785-793, 1983.

Jogiyanto. 2003. Sistem Teknologi Informasi Edisi 2: Pendekatan Terintegrasi Konsep Dasar, Teknologi, Aplikasi Pengembangan Dan Pengelolaan. Jogjakarta: Andi.

John Wiley And Sons. (1986)Information Sytem Theory And Practici, New York

Kahn, D., Wolfe, D.M., Quinn, R.P., Snoek, J.D., \& Rosenthal, R.A. (1964) Organizational Stress. Studies In Role Conflict And Role Ambiguity. John Wiley, New York.

Kemery, E.R., Bedeian, A.G.,Mossholder, K. W., \& Toulitios, J. (1985) Outcomes Of Role Stress: A Multi Sample Constructive Replication. Academy Of Management Journal, 28, 33-375.

Kilash Joshi \& Arun Rai. (2000) Impact Of The Quality Of Information Products On Information System User' Job Satisfaction: An Emprical Investigation, Journal Of Information System, 10, 323-345.

Leavitt, Harold J. 1978. Managerial Psychology, an introduction to Individual. Pairs, and Groups in Organization. Chicago: The Univercity of Chicago Press.

Lee, S.M., Kimy.R., \& Lee, J. (1995) An Empirical Study Of The Relationship Among And-User Information System Acceptance. Training And Effectiveness. Journal Of Management Information System, 12, 189-202.

Martin, Wainright. 2004. Managing Information Technology Fifth Edition, Prentice Hall.

Mulyadi, Rusma. (1999) Kualitas Jasa Sistem Informasi Dan Kepuasan Para Penggunanya, Jurnal Bisnis Dan Akuntansi, 1 (2),120-133.

Nunnally, Bernstein, I.H. 1994. Psychometric Theory, Edisi ke 3. New York : McGraw Hill.

Marretih, A. K. (2013). Work-Family Conflict Pada Ibu Bekerja . Sosial Budaya ,10(1),27-37

Kreitner, R., \& Kinicki, A. (2004). Organizational behavior. Boston, MA: McGraw Hill 
Irwin.

Pitt, L. F., Watson, R.T., \& Kavan, C.B. (1995) Service Quality: A Measure Of Information Systems Effectiveness. Mis Quarterly, 19(2), 173-187.

P. Robbins, Stephen. 2003. Organizational Behaviour Ten Edition. New Jersey: Prentice hall.

Haag dan Keen. 1996. Information Technology: Tomorrow's Advantage Today. Hammond: Mcgraw-Hill College.

Radityo, Dodi. 2006. Pengembangan Delone Dan Mclone Dalam Pengembangan Sistem Informasi Manajemen, Jurnal bisnis dan akuntansi, Universitas Diponegoro, Semarang

Rizzo, J.R., Lirtzman. (1970). Role Conflict and Ambiguity in Complex Organizations. Journal of Administrative, pp. 150-161.

Sekaran, Uma. 1992. "Research Methods for Business". Third Edition. Southern Illionis University

Susanto, Azhar.2004. Sistem Informasi Manajemen:Konsep Dan Pengembangannya. Bandung: Lingga Jaya

Van Sell, M., Brief, A.P. \& Schuler, R.S. (1981) Role Conflict And Role Ambiguity: Integration And Directions For Future Research', Human Relations, 34, 43-71.

Laudon, Kenneth C., and Jane P. Laudon, 2000.”Organization and Technology in The

Networked Enterprise"Management Information System, Six Edition, International Edition. www. prenhall.com/laudon.

Fujiati, Harris Kurniawan, Ria Eka Sari (2014),Rancang Bangun Sistem Informasi Pendistribusian Logistik Bencana Alam, Jurnal Seminar Nasional Informatika. 